\title{
SECURITIES INTERMEDIARIES
}

\author{
Țuțuianu Ion, Lecturer, $\mathrm{PhD}$ \\ UNIVERSITY OF BACĂU
}

\section{Abstract:}

The utility of comercial intermediation is obvious and represents a result of the needs created in the comercial surroundings. Doing comercial transactions on larger and larger scales calls for the need of using intermediaries for enhancing and improving the activity of the economical agent. This way, intermediation appears in between opposite related subjects:

The economical agents that offer goods and services, and on the other hand, the persons who need these things.

\section{Introductory considerations} regarding the capital market and securities intermediaries

In the contemporary world, the capital market constitutes a component of first importance in the economic life. In Romania, the formation of the capital market has represented a necessity, and its development is primarily imposing in the complex process of reorganization and creation of mechanisms which are specific to the market economy.

Therefore, a modern, competitive economy capable to adapt itself to the current requirements of globalization is not conceivable without the existence and the functioning of an efficient capital market.

As it was estimated in the specialty literature ,the capital is the sap that feeds the economy, and if the channels through which this sap is circulating are insufficient, inexistent or wrongly cut, the economic progress is questioned" ${ }^{\prime}$.

Through its specific mechanisms, the capital market is focusing and centralizing the capitals, but especially it must offer instruments and products which will ensure the fructification of placements and will cover the risks. The capital market is characterized by dynamism and innovation. It is a market which it is offering the most various investment opportunities and within which success depends on the degree of training and knowledge, skills, competence, flair and courage of each participant.

1 See: Gabriela Anghelache, „Bursa şi piața extrabursieră”, Publishing House Economică, Bucharest, 2000, p. 9.
Defining the capital market, it can be said that this represents the ensemble of relationships and mechanisms by means of which the available and dispersed capitals from the economy are directed towards economical agents or towards any public and private entities that solicit funds. $^{2}$

The existence of the capital market is determined by the request of capital for current treasury necessities and for investment and therewith it is conditioned by a real process of saving as fundament of the capital offer.

The capital market is binding, with the help of brokers, dealers and societies which intermediate security transactions, the issuers of stocks with individual and institutional investors.

Therefore the capital market it is functioning as a linking mechanism between those whose level manifests a surplus of capital - investors, and those that need the capital - issuers.

The capital flows between issuers and investors are emphasized by the emission and the transaction of some specific instruments, respectively, securities.

The capital market can be formally defined, like any market, as a ,meeting place for the sellers and the purchasers of securities".

\footnotetext{
${ }^{2}$ See: Gabriela Anghelache, op. cit., p. 11; for another definition with a different formulation, but, basically, with the same content, also see: Gabriela Anghelache, Carmen Obreja, „Piețe de capital şi tranzacții bursiere", A.S.E. Publishing House, Bucharest, 2000, p. 7.
} 
But the capital market concept has much deeper connotations which arise from the relations of assigning available resources with the purpose of fructifying them and satisfying the capital request from an economy.

From the point of view of its inclusion scope, in specialty literature ${ }^{3}$ there were structured two visions referring to the capital market:
a. - the Anglo-Saxon vision;
b. - the European continental vision ${ }^{4}$.
In the Anglo-Saxon vision, the capital market it is forming, together with the monetary market something which is called, by using an all-inclusive term, the financial market. In this context, the capital market is synonymous with the market of securities ${ }^{5}$ and ensures the investment of capital for medium and long terms.

The monetary market is attracting and placing the short term capital through the interbank market, the discount market, the market of trade effect, the market of deposit certificates, the market of Eurocurrencies, etc.

In the European continental vision, the capital market has a complex structure which contains:
a. - the monetary market;
b. - the mortgage market;
c. - the financial market.

The monetary market is the market of short and medium term capitals, being represented by the interbank market and by the market of negotiable titles of debts. On the interbank market are operating The Emissions Bank, the commercial banks, specialized banks, the public treasury, economy houses that act as creditors, but also debtors in case of completing own funds. The transactions on this market get the form of ,givingreimbursing" credit. On the market of negotiable titles of debts, all the operators are economic agents. The negotiated instruments

\footnotetext{
3 See, for instance: Gabriela Anghelache, Carmen Obreja, op. cit., p. 8.

${ }^{4}$ Of French origin.

${ }^{5}$ Securities market.

${ }^{6}$ Negotiable titles which certify the existence of a deposit account.

${ }^{7}$ Issued by commercial firms, except credit institutions.

${ }^{8}$ Issued by the public treasury.

${ }^{9}$ Issued by financial companies and firms.
}

are: certificates of deposit ${ }^{6}$, treasury notes ${ }^{7}$, treasury bills ${ }^{8}$, short term titles ${ }^{9}$.

The mortgage market is a market particular for the house building financing, on which act the organisms that are giving loans as real estate loans, the refinancing house which ensures the reunifying of the funds from the creditor banks and mortgage banks. This issue mortgage notes whose nominal value is equal to the size of the loan granted to private persons which solicit the necessary loan to build their houses.

By their sale on the capital market the mortgage notes transform in liquidities. To reimburse the loan, on the date of payment, the loan beneficiary buys from the market mortgage bills of a value equal to that of the received loan plus interest.

The financial market is the market of long term capitals, on which there are issued and transacted securities which act as support of the exchange of capitals. The financial market is the one where are bought and sold financial assets, without changing their nature. It expresses a direct relation between the owner and the user of the funds.

The practice in Romania is emphasizing the option for the Anglo-Saxon vision, according to which the capital market is a component of the financial market. The capital market presents itself as a connection mechanism between investors and issuers whose investing decision aims at two complementary objectives:

a. - profitability, respectively a high degree of capital fructification;

b. - liquidity, namely a more operative retrieval of the invested capital.

The monetary surplus obtained by profitability offers the possibility of new investments in assets with a high degree of liquidity. The improvement of the assets' structure in the economy and the acceleration of the rotation of the capital invested in these represent a factor which will increase profitability.

The capital market has the following

\section{characteristics:}

- it is an open market, meaning that the placement is performed in the great mass of investors and the security values transactions have a public character; 
- the market products are medium and long term instruments. On the capital market the money is invested for more than one year, while on the monetary market, resources are used for short term financing;

- securities, as market products, are characterized by negotiability and transferability. These can be transferred from one possessor to the other, offering the investor the possibility to sell that product at any time for a price specific to market conditions, or which results from negotiation at a certain moment;

- the transaction of securities is not direct, but intermediated. The intermediaries have an important role in what concerns putting in contact the issuers with the investors or the investors which own securities in their portfolio with those that want to buy them. The risk of the investment always belongs to the investors and not to the issuers.

\section{The role and the importance of} the capital market in the international trade. The capital market is offering modalities to invest, respectively to attract the capital, different than those specific to the banking system. As an alternative to the creation of bank deposits, the investors can purchase securities, and the issuers, in order to contract bank loans, can attract capitals by emission of shares and bonds.

From the banks' point of view, the shares are a „pillow” against income flow variability. These represent a permanent source of funds that do not require fixed payments or interest. The absence of shares implies a dependence upon debts, which leads to the incapacity to reimburse them in due time, in case the results are beyond expectations. The financing based on shares can also ensure funds for the reimbursement of high payment liabilities.

The share - as part of the issuing company's patrimony - it carries a risk of capital for the investor, in the way that the incomes brought by the latter vary in accordance with the manner in which that company is administered. If the company is dissolved, the share holder is indemnified only after all the loans shall be reimbursed. Thus, the cautious banks usually do not want to grant loans without asking the entrepreneurs to provide sufficient funds of their own. While the ratio between the loaned funds and own funds may vary according to local practices, however there is a limit that not even the banks will exceed.

The fixed assets, which represent a substantial part of the balance sheet of an industrial company, should be financed by permanent capital or, lastly, by long term liabilities. Short period bank loans seem to be an appropriate financing source, but only until a change in the company's profitability, a deterioration of the economic situation or a weakness in the financial system entail a credit line reduction.

From the entrepreneur's point of view, the capital presents not only a risk of reduction, but is, also, the mean through which it picks up the fruits of starting and conducting a business. If the company is successful, the entrepreneur's benefit from dividends and from the increased value of its shares can be much higher than the interest which the banker receives for the granted loan.

The need to finance enterprises based on the emission of shares in many countries has been marked by two factors:

- The rigid relations between banks and industrial groups;

- Appeal to government participations, credits and governmental guarantees;

Frequently the procurement of funds for investment in long term assets is considered as the primary economic contribution of the capital markets. This narrow point of view is ignoring other important contributions which the capital market may have over the economic development:

- efficiency, competitiveness and the solvency of the financial sector;

- mobilization of the financial economies;

- efficiency of assigning investments;

- firm solvency;

- decentralization of the property and the distribution of wealth;

- access of new and formation societies to share financing.

Potential benefits of the capital markets must be measured against costs and 
other disadvantages. These include the inevitability of the economic cycles and their impact over the capital procurement, the investors' trust and the strength of the financial system, the dangers of monopoly controls, the instability of prices and of interest rates, periods of high interest rates, after long periods of real negative rates, costs of mediating stock-markets and the institutions of the capital market and the need to regulate a subsector of the financial system.

The existence of an active market for shares and other securities ${ }^{10}$ creates alternatives for the bank system as regards both to depositors and to users of funds. The depositors can compare the incomes they could obtain by investing in shares or bonds with an interest rate for bank deposits, while the firms can compare the cost of different financing sources.

As important is also the potential contribution of share markets to the solvency of the financial system. The absence of some viable share markets leads to the growth of the ratio between the societies' loaned and own funds, thus weakening their structure of capital. This is endangering not only their long term viability, but also the solvency of the institutions from the financial system which grant loans

Another risk for the banking system is the discrepancy between short term deposits and the credit lines, a risk which is, practically, permanently present.

The bond markets which are liquids and assets are, also, helping to diminish one of the most critical problems of finance: availability of long term funds. While the investors want liquidity, the societies and the governments must make sure of the existence of some long term loans which will cover their assets for a long period or, in case of the governments, will finance development projects. Precisely for the reconciliation of these conflict situations there is the need of secondary markets. They allow the new emissions from the primary markets to be successful ${ }^{11}$.

Insofar as the shares and the bonds represent viable and relatively sure forms of investment offering an attractive income for a long period, they perform two functions:
- the shares generate a stimulus to save and invest, opposite to consumption, or to buy lands and real estate properties ${ }^{106}$ or to search abroad for more profitable investment options. The financial economies are promoted unlike the nonfinancial ones, and the rate of internal economies can grow per ensemble;

- the bonds compete with bank deposits that can be subject of interest rates control. This exerts a pressure to maintain the „controlled" interest rates closer to the „market" rates, which is possible to reflect the inflation and the penury of funds.

The efficient capital markets are forcing the companies to compete on an equal base for the investors' funds. The prices can be regarded as "label" for the value the investors associate their investment to. For a long period inadequate decisions of the companies' management generate dissatisfaction among investors. While closed companies can hide weak performances, at least for a while, open companies cannot afford that.

\section{Securities brokers on the capital market in Romania}

Succinctly, it is considered a securities broker the judicial person which is legally authorized by The National Securities Commission (CNVM) to exert the mediation of securities with a professional title, as a trade act, or for own purposes (dealer) or for third parties (broker).

Pursuant to Capital Market Law no. $297 / 2004^{13}$ are intermediaries - investment firms authorized by C.N.V.M., credit institutions authorized by the National Bank of Romania according to the relevant banking legislation, as well as other such entities authorized in Member or non-Member States to carry out investment services such as those referred to in art. 5 of the Law no. 297/2004, namely $^{14}$ :

\footnotetext{
${ }^{10}$ For instance, the bonds.

${ }^{11}$ Studies performed in a number of countries have shown that those who save immediately respond to the changes in the real income rate, at different financial instruments. For instance, when the control over the interest rates of deposits lead to real negative rates, the growth rhythm of deposits has rapidly decreased and grew back, as soon as the rates were positive.

${ }^{12}$ By this alimenting the speculations in this sector.
} 


\section{1. core services}

a) reception and transmission, on behalf of investors, of orders in relation to one or more financial instruments;

b)execution of such orders in relation to one or more financial instruments other than for own account;

c)dealing in any of the financial instruments for own account;

d)managing portfolios of investments in accordance with mandates given by investors on a discretionary, client-byclient basis, when such portfolios include one or more financial instruments;

e) the underwriting in any financial instruments and/or the placing of such financial instruments;

\section{2. non-core services:}

a) safekeeping and administration of financial instruments;

b) safe custody services;

c) granting credits or loans to an investor to allow him to carry out financial instruments transactions, where the firm granting the credit or loan is involved in the transaction;

d)advice to undertakings on capital structure, industrial strategy as well as advice and service relating to mergers and the purchase of undertakings;

e) other services related to financial instruments underwriting based on a firm engagement;

f) investment advice concerning financial instruments;

g)foreign exchange services where these are connected with the provision of the performed investment services.

The security societies carry out four great functions on the capital market ${ }^{15}$ :

- generate a mechanism to attract the capital by connecting the persons with money (investors) with those that need the money (issuers - societies, governments);

- generates a prices mechanism to evaluate the investments;

- generate a mechanism for investors to transform the investments in liquidities; proliferation of market products

In order to carry out all these functions, the security societies are performing services, acting or as intermediaries, or for them to buy/sell securities and offer advice to natural persons, to judicial persons or to governments.

Pursuant to art. 3 of the Law no. 297/2004, the intermediaries which provide investment services in Romania shall be registered in the C.N.V.M. Register as follows:

a) financial investment firms and intermediaries in non-Member States, based on the authorization granted by C.N.V.M.;

b) credit institutions, authorized by the National Bank of Romania;

c) equivalent of the credit institutions and the financial investment services companies authorized by the competent authorities of the Member States.

In all official papers, the intermediary must provide, besides its identification data, the number and the date of its being registered with the C.N.V.M. Register.

The rights granted by the provisions of Law no. 297/2004, with subsequent changes and completions, cannot be extended to the services provided as counterparty to the state, the National Bank of Romania or other public institutions or authorities that perform similar functions, in respect of monetary policy, exchange-rate, public debt and state reserve management.

This type of provisions shall be similarly enforced on credit institutions, while compliance supervision shall be carried out by C.N.V.M.

Compliance with authorization and capital adequacy requirements by credit institutions shall be supervised by the National Bank of Romania.

Financial investment services are provided by natural persons acting as agents of investment firms. These agents carry out their activity exclusively for the account of the intermediary whose employee they are and cannot provide investment services for their own account.

\footnotetext{
${ }^{13}$ Published in the Official Journal of Romania no. 571 of the $29^{\text {th }}$ of June 2004 .

${ }^{14}$ See, art. 5 Of the Law of the Capital Market nr. $297 / 2004$.
} 
No natural or judicial person can provide investment services without being registered with the C.N.V.M. Register.

C.N.V.M. sets procedures regarding the registration of investment services agents with the C.N.V.M. Register as well as regarding their situation of incompatibility.

Financial investment firms, hereinafter referred to as S.S.I.F are legal persons, established as joint-stock companies, issuers of nominative shares, according to Law no. $31 / 1990$, which have as their regular business the provision of investment services and which function only based on the authorization granted by C.N.V.M.

S.S.I.F. will be authorized by C.N.V.M. to provide investment services if they cumulatively meet the following conditions ${ }^{167}$ :

a) the firm is established under the legal form of a joint-stock company;

b) the registered office and the head office, as the case may be, representing the main office where the activity is managed and controlled are established in Romania;

c) its regular business exclusively refers to the provision of financial investment services;

d) the qualification, professional expertise and integrity of managers, directors, auditors and employees within the internal control department comply with the provisions set out in C.N.V.M. regulations;

e) evidence of the minimum initial capital, called-up and fully paid-up in cash, according to the investment services provided;

f) submission of the business plan, description of the organizational structure and of internal regulations;

g) submission of the contract concluded with a financial auditor, member of the Financial Auditors Chamber of Romania (CAFR) and who fulfils common criteria set up by C.N.V.M. and the Financial Auditors Chamber of Romania;

h) submission of shareholder structure, evidence of the identity and integrity of significant shareholders;

\footnotetext{
${ }^{15}$ Simona Fătu, „Piața românească de capital privită din interior”, Vox Publishing House, 1998, p. 107.

${ }^{16}$ See art. 8 of the Law no. $297 / 2004$.
}

i) other requirements laid down in C.N.V.M. regulations.

The authorization granted by C.N.V.M. to a S.S.I.F. shall clearly mention the investment services which it is allowed to provide according to the legal provisions.

Where close links exist between S.S.I.F. and another natural or legal person, C.N.V.M. grants authorization to provide investment services to the said S.S.I.F. only if those links do not prevent the exercise of its supervisory functions in compliance with the provisions of this law.

C.N.V.M. shall grant authorization to a S.S.I.F. within maximum 6 months from the date when the complete documentation required by the regulations in force has been submitted, or shall issue, provided that the application has been rejected, a motivated decision which may be contested within 30 days from the date of its communication.

S.S.I.F. may start its activity on the date authorization has been granted provided that it has also become a member of the Investor Compensation Fund.

Passing over the organizational part which we shortly have discussed in the former lines, at the end of this study we must also recollect a few words regarding the investment transforming mechanism. Thus, it must be well-known that investors wish to transform their monetary liquidness in investment and afterwards, the investment in liquidness, within an environment that wants to be as stable as it is possible. Also the securities firms want to perform for their client investment which shall not mean a major loss as regards the investment value. The firms which act on these markets. Called security firms create an important mechanism for investors. In case of the securities quoted on a market, the investors can act in the meaning of performing investment or obtaining liquidities, on a daily basis, without suffering a major loss as it comes to the value of the investment (fact which is owed to the transaction mechanism).

In other words, there can be external factors which will affect the value of the investment, and also the rumors in the economical world, but generally the value 
will not drop, simply due to the market mechanism.

At the same time it should be noted that securities firms also generate financial products because they study the client's necessities, offering them various possibilities to invest his money. The securities firms are permanently developing and improving financial instruments which are „cut" according to every client's specific needs.

\section{References:}

[1] Anghelache G., Piața de capital. Caracteristici. Evoluții. Tranzacții, Economică Publishing House, Bucharest, 2004.

[2] Anghelache G., Nan S., Badea D., Ioacara A., Reglementari actuale pe piața de capital, Economică Publishing House, Bucharest, 2005.

[3] Anghelache G., Piețe de capital şi tranzacții bursiere, Didactică şi Pedagogică Publishing House, Bucharest, 1997.

[4] Anghelache G., Bursa şi piața extrabursieră, Economică Publishing House, Bucharest, 2000.

[5] Anghelache G., Obreja C., Piețe de capital şi tranzacții bursiere, ASE Publishing House, Bucharest, 2000.

[6] Angheni S., Volonciu M., Stoica C., Lostun M.C., Drept comercial, Oscar Print Publishing House, Bucharest, 2000.

[7] Badea D.G., Piața de capital şi restructurarea economică, Economică Publishing House, Bucharest, 2000.

[8] Bufan R., Reorganizarea judiciară şi falimentul, Lumina Lex Publishing House, Bucharest, 2001.

[9] Căpățînă O., Societățile comerciale, Lumina Lex Publishing House, Bucharest, 1991.

[10] Căpățână O., Ştefănescu B., Tratat de drept al comerțului internațional, Vol. II, Academiei Publishing House, Bucharest, 1987.

[11] Stanciu D., Cărpenaru, Procedura reorganizării şi lichidării judiciare, Atlas Lex Publishing House, Bucharest, 1996.

[12] Stanciu D., Cărpenaru, Drept comercial român, ed. a IV-a, ALL Beck Publishing House, Bucharest, 2002.

[13] Cârcei E., Funcționarea şi încetarea societăților comerciale pe acțiuni, Economică Publishing House, Bucharest, 1996.

[14] Ciobanu G., „Bursele de valori şi tranzacțiile la bursă”, Economică Publishing House, Bucharest, 1997.

[15] Chilic-Micu B., Bursa de valori, Economică Publishing House, Bucharest, 1997.

[16] Dardac N., Basno C., Bursele de valori: dimensiuni şi rezonanțe social-economice, Economică Publishing House, Bucharest, 1997.

[17] Durand M., Bursa, Humanitas Publishing House, Bucharest, 1992.

[18] Fătu S., Piața românească de capital privită din interior, Vox Publishing House, 1998.

[19] Gallois D., Bursa - Origine şi evoluție, Teora Publishing House, Bucharest, 1999.

[20] Popa I., Bursa, Adevărul Publishing House, Vol. I şi II, 1993, 1994.

[21] Vonica R.P., Drept comercial.Reorganizarea judiciară şi falimentul, Victor Publishing House, Bucharest, 2001. 